\title{
The Posing of Arithmetic Problems by Math- ematically Talented Students
}

\author{
Johan Espinoza González ${ }^{1}$, José Luis Lupiáñez Gómez, ${ }^{2}$ \\ and Isidoro Segovia Alex ${ }^{2}$ \\ ${ }^{1}$ Universidad Nacional de Costa Rica \\ ${ }^{2}$ Departamento de Didáctica de la Matemática, Universidad de Granada.
}

\section{Costa Rica / Spain}

Correspondence: Johan Espinoza González. Universidad Nacional, Sede Regional Brunca. Postal code: 348000. San Isidro del General, Pérez Zeledón, Costa Rica. E-mail: jespinoza@una.cr

(C) Education \& Psychology I+D+i and Ilustre Colegio Oficial de la Psicología de Andalucía Oriental (Spain) 


\section{Resumen}

Introducción. Se presenta el análisis de los problemas aritméticos planteados por un grupo de estudiantes considerados con talento matemático ante dos tareas de invención de problemas y su comparación con las actuaciones que presentan un grupo estándar de estudiantes de un colegio público ante las mismas tareas. Este estudio se centró en caracterizar e identificar las diferencias entre las producciones de ambos grupos, con base en un esquema de análisis confeccionado en esta investigación.

Método. La muestra está conformada por dos grupos de estudiantes. El primero está compuesto por 21 estudiantes identificados con talento matemático y el segundo está formado por 19 estudiantes de segundo curso de Educación Secundaria de un colegio público. Ambos grupos contestaron dos tareas de invención de problemas aritméticos que fueron confeccionadas en este estudio. Los resultados se analizaron con base en tres categorías de análisis y algunas variables que están relacionadas con la estructura sintáctica, semántica y matemática de los mismos.

Resultados. Los problemas inventados por el grupo de estudiantes con talento en matemática presentan mayor riqueza que los del grupo del colegio público, ya que están conformados por una mayor cantidad de proposiciones, emplean diferentes tipos de números, requieren más pasos y procesos de cálculo distintos para ser resueltos y presentan una mayor cantidad de relaciones semánticas distintas. Además, los resultados muestran algunos atributos que caracterizan a los estudiantes con talento en matemática cuando resuelven tareas de invención de problemas.

Conclusión. El instrumento de invención de problemas y el esquema analítico empleado permitieron describir y explorar la actuación de un grupo de estudiantes considerados con talento matemático. Además, las tres categorías de análisis y la solución de cada problema dan lugar a diez componentes cuyos valores caracterizan la riqueza de los problemas inventados por los sujetos. Por último, el análisis estadístico realizado refuerza las diferencias encontradas entre las producciones de ambos grupos en estudio.

Palabras Clave: Talento matemático, invención de problemas, riqueza de enunciados, problemas aritméticos, Educación Matemática. 


\section{The posing of arithmetic problems by mathematically talented students \\ Abstract}

Introduction. This paper analyzes the arithmetic problems posed by a group of mathematically talented students when given two problem-posing tasks, and compares these students' responses to those given by a standard group of public school students to the same tasks. Our analysis focuses on characterizing and identifying the differences between the productions of both groups, based on an analytic framework designed in this study.

Method. The sample is composed of two groups of students. The first consists of 21 students identified as mathematically talented and the second of 20 secondary students in a public school. Both groups completed two tasks of posing arithmetic problems designed in this study. The results were analyzed based on three categories of analysis and variables related to the problems' syntactic, semantic, and mathematical structure.

Results. The problems posed by the group of mathematically talented students are richer than those of the group of public school students. The talented students' problems are composed of a greater number of propositions, use different types of numbers, require more steps and different calculation processes to solve, and have a higher number of different semantic relationships. Furthermore, the results show some attributes that enable us to characterize mathematically talented students when solving problemposing tasks.

Conclusion. The problem-posing instrument and the analytical diagram enabled description and exploration of the performance of a group of mathematically talented students. Moreover, the three categories of analysis used and the solvability of each problem produced ten components whose values characterize the wealth of problems that the subjects invented. Finally, statistical analysis reinforces the differences between the productions of the two study groups.

Keywords: Mathematical talent, problem posing, richness of statements, arithmetic problems, Mathematics Education 


\section{Introduction}

This study focuses on characterizing the productions when posing arithmetic problems of a group of subjects identified as mathematically talented, and compares these productions to productions of a standard group of students. The research problem tackled in this study thus includes two fields of study: problem posing and mathematically talented subjects. The field of problem posing originated in a line of research that studies of problem solving (Castro, 2008), and a number of studies (Freudenthal, 1973; Polya, 1979; Polya, 1954; Brown \& Walter, 1990; Ellerton, 1986; Castro, 2011; Espinoza, Lupiáñez \& Segovia, 2014) attest to its richness as a research focus.

To improve problem-solving abilities, research (Leung \& Silver, 1997) has tackled several topics: studying children with mathematical talent (Krutetskii, 1976; Ellerton, 1986; Kesan, Kaya \& Güvercin, 2010), gaining a view of students' understanding of mathematical concepts and procedures (English, 1997; Brown \& Walter, 1993), and studying how students handle and structure their mathematical knowledge (Pelczer \& Gamboa, 2008).

We find that the topic of mathematical talent is of interest for the community of educators and researchers in Mathematics Education (Benavides, 2008), as demonstrated, for example, by the Topic Study Groups proposed at the ICME 10 (TSG4) and ICME 11 (TSG6). Similarly, Castro (2008) notes that studies of mathematical talent have centered on three main research focuses: characterizing mathematical talent, establishing mechanisms to identify it, and providing alternatives for intervention. In focusing on characterization of mathematical talent, some researchers (Krutetskii, 1976; Greenes, 1981; Pasarín, Feijoo, Díaz \& Rodríguez, 2004; Banfield, 2005) observe and analyze the thinking characteristic of talented students, generally through problem-solving tasks. Their research concludes that the reasoning talented students demonstrate is very different from that of ordinary students in terms of speed and depth (Kesan et al., 2010).

Other studies characterize mathematical talent using problem-posing tasks. Krutetskii (1976), for example, reports that mathematically talented students naturally saw the problems that arose from the information given, whereas students with low mathematics ability did not, even when the interviewer provided advice. 
Ellerton (1986) shows that the problems posed by students with more ability require greater calculation difficulty, have a larger number of operations, involve a more complex number system, and use mathematical language with greater fluency than do the problems posed by less able classmates. The study also concludes that there is little evidence to suggest that the less able students planned their problems, whereas the problems produced by more able students showed greater consistency with the rest of the problem, suggesting some planning. Further, it was observed that the more able students know how to solve their own problems, while their less able classmates do not always know where to begin.

Silver \& Cai (1996) also proposed this type of task to students with higher and lower mathematics ability. Their results indicate that the high group of students (greater mathematical ability) generated not only more mathematical problems but also more complex problems than their classmates (low group) and that the students' problem-solving performance correlated highly with their performance in posing problems. It was also observed that students in the high group posed a significantly higher number of mathematical problems that involved two or more semantic relationships than did their classmates in the low group.

Finally, Kesan et al. (2010) study the effect of problem-posing activities on the development of mathematical abilities in 40 mathematically talented students. The study concludes that this type of activity is effective in improving students' problem-solving abilities, as well as their mathematical performance, especially for non-routine tasks and open ended problems.

Despite these antecedents, few studies relate these two topics to show the specific characteristics that students with mathematics talent demonstrate when given problem-posing tasks, or whether problem posing can be used as a diagnostic technique. We therefore focus on characterizing the actions of a group of mathematically talented students when given semistructured tasks of posing arithmetic problems constructed especially for this study. We then compare the actions of this group to those of a group of students from a public school in response to the same task. We also wish to identify indexes of the use of problem posing as a tool to identify mathematically talented students.

We will now present some concepts related to mathematically talented subjects, mathematical problem posing, and arithmetic problems. 


\section{Johan Espinoza et al.}

\section{Mathematical talent}

Some authors hold that talented students have characteristics that differentiate them from their classmates. For example, Greenes (1981) notes that talented students have a higher pace of learning, excellent memory, exceptional verbal and reasoning capabilities, and great powers of abstraction. But who are the talented students?

We can distinguish five notions of talent oriented to different issues: achievement or performance, the innate ability, interaction between the innate ability and the environment, and cognitive and systematic models (Villarraga, Martínez \& Benavides, 2004). This study aims to analyze the notion of talent oriented to achievement or performance, since we focus on studying the performance of mathematically talented students.

In studying a specific talent, mathematical talent, we adopt the definition of Passow (1993) to refer to students that have shown specific aptitude in the area of mathematics. We adopt this definition because one of the groups chosen is composed of students that demonstrate specific aptitudes in the area of mathematics based on selection tests. Ramírez (2012) summarizes the findings of various researchers on the abilities that characterize such subjects' performance in mathematics. Among them, Freiman (2006) proposes abilities such as spontaneously questioning issues that go beyond school tasks, transitioning easily between different mathematical structures, focusing on the key points of problems, developing efficient problem-solving strategies, and producing original, valuable, and extensive ideas, among others. It is precisely this last ability that we use to establish the connection with problem posing.

Various methods are used in identifying mathematical talent, with both qualitative and quantitative focuses. Standardized tests are the method most frequently used, even though they run the risk of rejecting children that should be identified as mathematically talented (Benavides, 2008). Due to this shortcoming, research in Spain recommends using additional instruments to supplement those traditionally used in order to identify a greater number of talented students (Hernández \& Gutiérrez, 2014). Some authors (Krutetskii, 1976; Ellerton, 1986, Kesan et al., 2010) stress the use of problem posing as a tool both to identify mathematically talented students and to understand the nature of the mathematical abilities of mathematically talented children. Studies by Getzels and Jackson (1962; cited in Silver, 1994) and Balka (1974), for example, use problem-posing activities in the process of identifying creative 
individuals, as creativity is a trait present in highly able subjects (Marugan, Carbonero, Torres \& León, 2012).

\section{Problem posing}

The term "problem posing" (Kilpatrick, 1987; Brown \& Walter, 1993; Silver, 1994; English, 1997) (in spanish "invención de problemas o planteamiento de problemas") consists of formulating new problems, as well as reformulating given situations (Silver, 1994; Silver \& Cai, 1996; English, 1997). For Silver (1994), this process can be performed in three different ways: (a) before solving a problem, when one seeks not to solve but to formulate a problem from a situation or experience, (b) during solution of a complex problem, by reformulating it into simpler situations, and (c) after solving a problem, in seeking to modify the problem's objective, condition, or question in order to generate new problems.

Further, three ways have been identified to formulate problems: free situations, semistructured situations, and structured situations (Stoyanova, 1998). In free situations, students have no restrictions in posing problems. In semi-structured situations, they are asked to pose problems based on some experience or situation. Finally, structured situations require reformulating given problems or changing the conditions of the problem.

We thus consider problem-posing as a complex mathematical process in which one or more problems are constructed from the personal interpretation or meaning assigned to a specific situation or problem given beforehand.

\section{Arithmetic problems}

Since this study proposes two tasks for posing arithmetic math problems, we believe it is relevant to explain the notion of mathematical problem used here. We adopt the notion proposed by Castro (1991), who indicates five components that a situation should include to be considered a mathematical problem: a proposition (oral or written statement), some known data; an intention (to mobilize one or more persons to solve it), a goal (to arrive at a result) and a process (way of acting to achieve the result).

We consider a problem as arithmetical if it is a mathematical problem that provides quantitative information, the condition in the statement expresses quantitative relationships between the data, and the question refers to calculation of one or several quantities or rela- 
tions between quantities (Puig \& Cerdán,1988). We also consider problems as arithmetical if they use unknowns or equations, as long as solution of the problem is based on an arithmetical or predominantly arithmetical technique (Gasco \& Villarroel, 2014).

In classifying arithmetic problems, Puig \& Cerdán (1988) argue that an arithmetic problem may be classified according to its operator structure, as: additive with one stage, multiplicative with one stage, additive with more than one stage, multiplicative with more than one stage, and combining various operations. The latter, also called a mixed problem, combines additive and multiplicative structures, and solving it requires more than one relationship between the data (Castro et al., 1997). In classifying the study variables for arithmetic problems, Puig \& Cerdán (1988) stress the syntactic variables related to the order and relationships of the words and symbols the statement contains-length of statement, grammatical complexity, presentation of data, location of the question, etc. Castro (1995) identifies another type of variable, termed an interrogative proposition, which is related to the problem question and can be made about a designation or relationship. Silver \& Cai (2005) add a third type of interrogative proposition, termed conditional, in which the question establishes a condition between the two elements, for example: If María walked 300 meters more than Pedro, how many meters did María walk? These authors associate this variable with the linguistic complexity of a problem.

Castro, Rico \& Gil (1992) stress the statement's numerical data, which can be distinguished by the set and size of the numbers, inclusion of superfluous data, operations needed to obtain the result, and algorithm used in each operation. In discussing the latter variable, Castro et al. (1997) classifies an arithmetic problem whose solution involves only addition and multiplication as a two-process problem.

Finally, we must consider the semantic component (Nesher, 1982; cited in Puig \& Cerdán, 1988), which is classified into change, combination, comparison, and equation for additive problems; and multiplicative comparison, equation, isomorphism of measures, and product of measures for problems with a multiplicative structure.

\section{Objectives}

The general study goal is to describe, analyze, and characterize the capability of a group of mathematically talented students in performing tasks of posing arithmetic word Electronic Journal of Research in Educational Psychology, 14(2), 368-392. ISSN:1696-2095. 2016. no. 39 
problems. We also seek to determine indexes of using problem posing as a tool to identify mathematically talented students.

To achieve this goal, we proposed the following specific objectives: (1) to build an instrument to pose problems with two tasks or semi-structured situations for posing verbal arithmetic problems, (2) to define an analytic method based on categories and variables that permit characterization of the productions of both groups of students responding to the task of posing arithmetic problems, and (3) to identify differences between the problems posed by the two groups based on the categories and components for analysis defined.

\section{Method}

\section{Participants}

The study subjects are two groups of Spanish students with different characteristics. The first, the "talent group," is composed of 21 mathematically talented students who participated in the project ESTALMAT Andalusia ${ }^{1}$ during academic year 2010-2011 and who are 13-15 years old. This project seeks, for a period of two years, to detect and stimulate the precocious mathematical talent of a group of students in Andalusian schools who were chosen through a selection test. ${ }^{2}$ The second, "standard" group was composed of 19 students in the third year of secondary education at the Nazarí Secondary School, located in Salobreña, a province of Granada. These students were 14-15 years old.

\section{Instrument}

We developed a questionnaire composed of two tasks corresponding to semistructured situations for posing problems (Stoyanova, 1998). These tasks permitted the students to put into practice elements related to talent, such as their abilities, mathematical knowledge, and creativity. This last ability is considered as one of the traits defining gifted people (Marugan, Carbonero, Torres \& León, 2012).

\footnotetext{
${ }^{1}$ The program ESTALMAT (Stimulation of Mathematical Talent) is an initiative of the Royal Academy of Exact, Physical, and Natural Sciences of Spain. In concrete terms, it is a training program for mathematically talented students. Basic information about the program may be found at http://www.estalmat.org. The Andalusian version of the program is available at http://thales.cica.es/estalmat.

${ }^{2} \mathrm{http}: / /$ thales.cica.es/estalmat/?q=node/39. 
To design the instrument, we took into account the type of information the problem provided, the type of information that remained unknown, and that the school context presented in the situation was familiar to the students (Moses, Bjork, \& Goldenberg, 1990). We also asked the students to pose problems that they considered as difficult to solve, since we were interested in their taking the activity as a challenge and making an effort to put their knowledge, abilities, creativity, and prior experiences into practice in posing problems. This instruction has been used effectively in other studies, such as Ayllón (2012). The instrument was reviewed and analyzed by experts in Mathematics Education and then applied in a pilot test with a small group of students. The end result was as follows:

Task 1. Using the information in the following figure, pose a mathematical problem that you think is hard to solve and that requires using one or several of the operations of addition, subtraction, multiplication, or division to solve. If necessary, you may add more data or information.

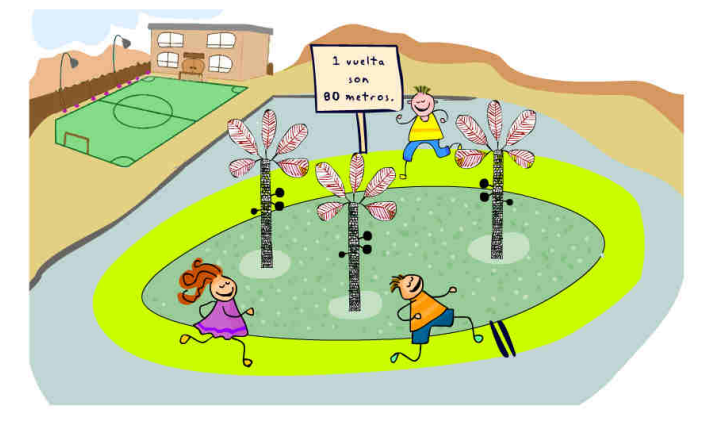

Figure 1. Image used in the first task ${ }^{3}$

Task 2. Using the information in the following figure, pose a mathematical problem that you think is hard to solve and that requires using one or several of the operations of addition, subtraction, multiplication, or division to solve. If necessary, you may add more data or information.

"A train with four passenger cars leaves a station for Malaga at 9:00. The train has a maximum capacity of 294 passengers."

\footnotetext{
3 Figure obtained from http://ntic.educacion.es/w3/eos/MaterialesEducativos/mem2009/problematic/menuppal.html. 


\section{Description of the categories and components of analysis}

To develop the categories for analysis, we considered the characteristics of this study and reviewed the study variables for arithmetic problems proposed by Puig \& Cerdán (1988), Castro (1995), and Castro et al. (1992); and the diagrams used by Leung \& Silver (1997), Silver \& Cai (2005, 1996), Cázares (2000), and Ayllón (2012). This review led us to define three categories for analysis, with study variables for each, explained in greater detail in Espinoza, Lupiáñez \& Segovia (2015).

In the first category, termed syntactic structure, we studied length of statement, type of interrogative proposition, and type of numbers used. Length of statement was analyzed according to the number of propositions present that correspond to explicit expressions in the text that assign a numerical value or quantity to a variable, or that establish a quantitative relationship between two variables. Type of interrogative proposition is related to the problem question and is classified into designative, conditional, or relational (Silver \& Cai, 2005). The numbers can be whole or rational, the latter in their different representations, expressed as decimals or fractions.

The second category, termed mathematical structure, was analyzed according to type of operator structure (additive, multiplicative, mixed) and number of stages or steps in each structure to solve the problem, type of arithmetic operation (addition, subtraction, multiplication, division), number of different calculation processes involved in solving the problem (following Castro et al. [1997]), and number of different steps to solve the problem.

Finally, in the category semantic structure, we studied semantic structure of the problems (Change, Combination, Equation, and Comparison for additive problems and Isomorphism of measures, Comparison, and Product of measures for multiplicative problems) and number of different semantic relationships in the statement.

The components of the three categories and the problem solution permit us to characterize the students' statements and evaluate their richness. To study whether significant differences exist between the productions of the talent and standard groups, we applied Yates's continuity correction of the Chi-square statistic, as the data fulfill the requirement that the expected values of at least $80 \%$ of the contingency cells be greater than 5 . We used commer- 
cial software (SPSS for Windows, version 19; SPSS Inc., Chicago, IL, USA) to perform this analysis.

Diagram to evaluate the solution of the students' productions

All of the students' productions were classified into solvable and unsolvable problems. Among the latter, we found unsolvable problems with characteristics that were important to analyze. We therefore classified these problems, distinguishing those that were incomplete (Puig \& Cerdán, 1988) from those that showed either numerical or conceptual mathematical incompatibility. The incomplete solvable and unsolvable mathematics problems and those that showed numerical mathematical incompatibility were analyzed based on their syntactic, semantic, and mathematical structure, explained above. The mathematical problems that showed conceptual mathematical incompatibility were analyzed only based on their syntactic structure, as it was not possible to analyze the other two structures. Figure 2 shows the diagram used to evaluate the students' productions.

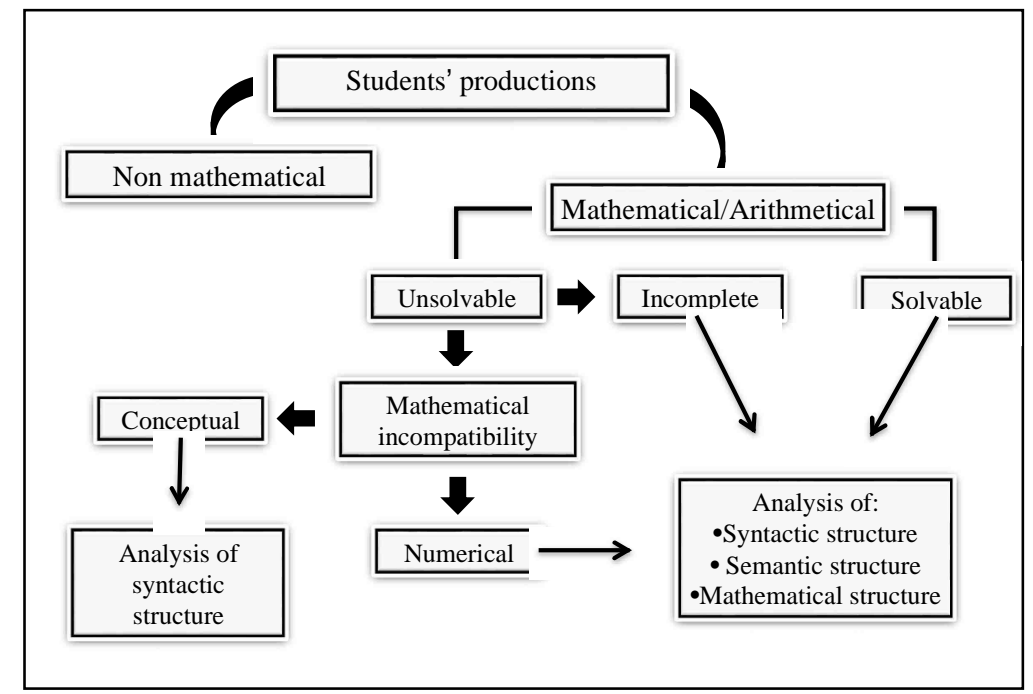

Figure 2. Diagram to evaluate the students' productions

\section{Procedure}

After establishing the goals and designing the instruments and diagram to evaluate the students' productions, we requested the collaboration of the teachers of the two groups to apply the problem-posing instrument during a 20-minute time period, separately to each group. The instrument was applied in the same way in both groups and consisted of the interviewerresearcher giving each student the two sheets with the problem-posing tasks and telling the students that the activity formed part of a research project at the Department of Mathematics 
Education at the University of Granada that was studying mathematical problem-posing processes.

\section{Results}

In this section, we present the main results obtained from the productions of the two groups of students in response to the two tasks proposed. We first present the general characteristics of the problems posed and then explain the results obtained according to syntactic, mathematical, and semantic structure of the problems.

\section{General characteristics of the problems posed}

First, we found that all of the statements the students posed were mathematical problems and that $65 \%$ were solvable. It is interesting to note that the students in the standard group posed a larger number of solvable problems (74\%) than those in the talent group (57\%). This result is surprising, as the opposite is expected; without performing another, more extensive study to confirm which factors influenced this result, we can only suggest various factors: more positive attitude of the talent group toward mathematics, less anxiety and fear of making a mistake, not having to solve the problems they posed, etc.

We also found that the problems that were unsolvable due to mathematical incompatibility represent $22.5 \%$ of the total (18 problems, 12 posed by the talent group and 6 by the standard group) and the incomplete problems 12.5\% (10 problems, 6 posed by the talent group and 4 by the standard group). Together, these two types of problem represent $35 \%$ of the mathematical problems produced by the students.

Table 1. Distribution of problems according to solvability and group to which the student belongs

\begin{tabular}{cccccccc}
\hline & & & \multicolumn{2}{c}{ Unsolvable problems } & \\
\cline { 4 - 6 } & Solvable problems & Incomplete & \multicolumn{2}{c}{$\begin{array}{c}\text { Mathematical in- } \\
\text { compatibility }\end{array}$} & \\
& & & & & Total \\
& Frequency & $\%$ & Frequency & $\%$ & Frequency & $\%$ & \\
\hline Talent group & 24 & 57.1 & 6 & 14.3 & 12 & 28.6 & 42 \\
Standard group & 28 & 73.7 & 4 & 10.5 & 6 & 15.8 & 38 \\
Total & 52 & 65.0 & 10 & 12.5 & 18 & 22.5 & 80 \\
\hline
\end{tabular}


The following is an example of a problem posed with numerical mathematical incompatibility, since 229 cannot be divided by 3: A train with four cars leaves the Madrid train station at 9:00, headed for Malaga. All of the seats have been sold (294), but at the last moment one of the cars, which has a capacity of 65 passengers, breaks down and has to remain at the station. If the other cars each have the same capacity, how many passengers can get into each car?

An example of a problem classified as incomplete because it did not indicate the total number of people who remained on the train at the last stop reads as follows: On this trip, the train is full. At the first stop, 2 couples get off, one with one child more than the other, and a number of people get on so that the total number of people is 290. At the second stop, 10 couples get off and 15 people get on. At the last stop before arrival, 3 people get off and triple the total number of children belonging to the first two couples get on. How many people get on at the first stop, and how many children does each couple (at the 1st stop) have?

Since both groups posed unsolvable problems with interesting characteristics for analysis, we believe it beneficial to study this kind of problem based on each of the study variables used in the research.

\section{Analysis of syntactic structure}

Length of sentence. We find that the average number of propositions in the problems is greater in the talent group (5.27) than in the standard group (3.44). The following table presents the characterization of the problems according to this variable

Table 2. Distribution of problems by number of propositions, task, and group to which the student belongs

\begin{tabular}{lcccc|cccc}
\hline \multirow{2}{*}{ Number of propositions } & \multicolumn{4}{c|}{ Talent group } & \multicolumn{4}{c}{ Standard group } \\
\cline { 2 - 9 } & T1 & T2 & Total & $\%$ & T1 & T2 & Total & $\%$ \\
\hline One or two propositions & 5 & 0 & 5 & 11.9 & 6 & 2 & 8 & 21.1 \\
Three propositions & 2 & 1 & 3 & 7.1 & 5 & 5 & 10 & 26.3 \\
Four propositions & 3 & 2 & 5 & 11.9 & 6 & 2 & 8 & 21.1 \\
Five or six propositions & 7 & 5 & 12 & 28.6 & 2 & 7 & 9 & 23.7 \\
Seven or more propositions & 4 & 13 & 17 & 40.5 & 0 & 3 & 3 & 7.9 \\
\multicolumn{1}{r}{ Total } & 21 & 21 & 42 & 100.0 & 19 & 19 & 38 & 100.0 \\
\hline
\end{tabular}


Table 2 shows that $69.1 \%$ of the problems posed by the talent group are composed of five or more propositions, as opposed to $31.6 \%$ of the questions posed by the standard group. We also see that approximately half of the problems posed by the standard group (47.4\%) have three or fewer propositions, whereas the talent group proposed $19 \%$ with this characteristic.

On the other hand, we find that the average number of propositions in the unsolvable problems (5.58) is greater than the average in the solvable problems (5.04), since we observe that the students pose a higher proportion of unsolvable problems with five or more propositions $(77.8 \%)$ than of solvable problems with this characteristic $(62.5 \%)$.

The Chi-square analysis showed that the differences between the two groups are significant, as the associated p-value is 0.004 , permitting us to reject the null hypothesis. That is, the variables Group and Number of propositions are dependent.

Interrogative proposition. Most of the interrogative propositions posed by the students in the talent and standard groups are designative (52.4\% and $60.5 \%$, respectively). The following is an example of a problem with a designative interrogative proposition related to the second task: At 9:00 a.m., a train leaves with 50 passengers; at 11:00, it returns with 70 passengers; it leaves again and returns with 30 passengers. What is the total number of passengers who have gotten on and off?

Types of numbers used. We observe that both groups preferred to use natural numbers in posing their problems (97.6\% of the talent group and $97.4 \%$ of the standard group). We also find that $43.9 \%$ of the problems posed by the talent group use rational numbers expressed in both decimal and fraction form, whereas $18.5 \%$ of the problems posed by the standard group have this characteristic. Further, the talent group posed almost double the proportion of problems with two or more types of numbers than the standard group, $34.1 \%$ and $18.4 \%$, respectively.

\section{Analysis of mathematical structure}

We analyzed 78 problems in this category, since two problems with mathematical incompatibility are impossible to solve, even with additional information. 
Type of operator structure and number of stages to solve the problem. We find that most of the problems posed by both groups are of mixed structure, but the talent group posed a higher proportion (80\%) than did its classmates in the standard group (55.3\%). In contrast, the standard group posed a higher proportion of problems with multiplicative structure $(31.5 \%)$ and additive structure $(13.1 \%)$ than did their classmates in the talent group $(17.5 \%$ and $2.5 \%$, respectively). Further, we find that $97.5 \%$ and $94.8 \%$ of the problems posed by the talent and standard groups, respectively, have more than one stage. The following table shows the results obtained for this variable.

Table 3. Distribution of problems by operator structure, number of stages, task, and group to which the student belongs

\begin{tabular}{|c|c|c|c|c|c|c|}
\hline \multirow{2}{*}{$\begin{array}{c}\text { Operator structure and number of } \\
\text { stages }\end{array}$} & \multicolumn{3}{|c|}{ Talent group } & \multicolumn{3}{|c|}{ Standard group } \\
\hline & $\mathrm{T} 1$ & $\mathrm{~T} 2$ & $\%$ & $\mathrm{~T} 1$ & $\mathrm{~T} 2$ & $\%$ \\
\hline Mixed structure & 12 & 20 & 80.0 & 8 & 13 & 55.3 \\
\hline Multiplicative, two or more stages & 6 & 0 & 15.0 & 9 & 2 & 28.9 \\
\hline Additive, two or more stages & 0 & 1 & 2.5 & 1 & 3 & 10.5 \\
\hline Multiplicative, one stage & 1 & 0 & 2.5 & 1 & 0 & 2.6 \\
\hline Additive, one stage & 0 & 0 & 0.0 & 0 & 1 & 2.6 \\
\hline Total & 19 & 21 & 100.0 & 19 & 19 & 100.0 \\
\hline
\end{tabular}

In this case, if we classify the values of the variable structure into additive, multiplicative, and mixed, the associated p-value for the Chi-square is 0.045 , which also shows significant differences between the two groups. Examining the relation of the problem's solvability to this variable, we find that both groups posed more unsolvable than solvable mixedstructure problems. This was not the case, however, of problems with multiplicative and additive structure, the majority of which were solvable.

Type of operation and number of processes involved in solving the problem. The following table shows classification of the problems according to type of operation.

Table 4. Distribution of problems by type of operation and group to which student belongs

\begin{tabular}{lcccc}
\hline \multicolumn{1}{c}{ Type of operation } & $\begin{array}{c}\text { Talent } \\
\text { group }\end{array}$ & $\%$ & $\begin{array}{c}\text { Standard } \\
\text { group }\end{array}$ & $\%$ \\
\hline Addition & 1 & 2.5 & 3 & 7.9 \\
Multiplication & 2 & 5.0 & 4 & 10.5 \\
Addition-Multiplication-Division & 4 & 10.0 & 1 & 2.6 \\
Addition-Subtraction-Multiplication & 5 & 12.5 & 3 & 7.9 \\
Multiplication-Division & 6 & 15.0 & 7 & 18.4
\end{tabular}




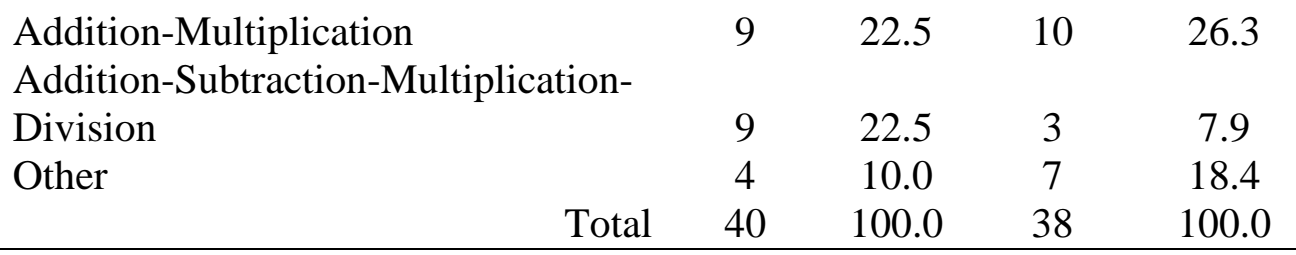

According to Table 4, $60 \%$ of the problems in the talent group involved use of multiplication-division, addition-multiplication, and addition-subtraction-multiplication-division. In the standard group, $55.2 \%$ of the problems required operations of multiplication, multiplication-division, and addition-multiplication. In this case, the p-value produced by the Chisquare is 0.031 , showing significant differences between the groups.

As to number of processes (Castro et al. 1997) involved in solving the problem (Table 5), we find that the talent and standard groups posed $92.5 \%$ and $81.6 \%$, respectively, of problems with two or more processes. We also see that $47.5 \%$ of the problems produced by the talent group have three or more different processes, in contrast to $21.1 \%$ of the problems for the standard group. We should highlight that the students in the talent and standard groups posed similar proportions of problems with two or three processes $(70 \%$ and $73.7 \%$, respectively). The $\mathrm{p}$-value for the Chi-square test is 0.018 , indicating significant differences between the two groups. Finally, we find no differences in the number of processes involved in solvable and unsolvable problems.

Table 5. Classification of problems by number of different processes involved in solving, task, and group to which the student belongs

\begin{tabular}{|c|c|c|c|c|c|c|}
\hline \multirow{2}{*}{$\begin{array}{c}\text { Number of different } \\
\text { processes }\end{array}$} & \multicolumn{3}{|c|}{ Talent group } & \multicolumn{3}{|c|}{ Standard group } \\
\hline & $\mathrm{T} 1$ & $\mathrm{~T} 2$ & $\%$ & $\mathrm{~T} 1$ & $\mathrm{~T} 2$ & $\%$ \\
\hline One process & 2 & 1 & 7.5 & 4 & 3 & 18.4 \\
\hline Two processes & 11 & 7 & 45.0 & 11 & 12 & 60.5 \\
\hline Three processes & 4 & 6 & 25.0 & 3 & 2 & 13.2 \\
\hline Four processes & 2 & 7 & 22.5 & 1 & 2 & 7.9 \\
\hline Total & 19 & 21 & 100.0 & 19 & 19 & 100.0 \\
\hline
\end{tabular}

Number of different steps to solve the problem. We see that the average number of steps to solve the problem is greater in the talent group (3.95) than in the standard group (2.92). Table 6 shows the distribution of problems according to this variable.

Table 6. Classification of problems by number of differ- 


\section{Johan Espinoza et al.}

ent steps to solve them, task, and group to which student belongs

\begin{tabular}{|c|c|c|c|c|c|c|}
\hline \multirow{2}{*}{$\begin{array}{l}\text { Number of differ- } \\
\text { ent steps }\end{array}$} & \multicolumn{3}{|c|}{ Talent group } & \multicolumn{3}{|c|}{ Standard group } \\
\hline & $\mathrm{T} 1$ & $\mathrm{~T} 2$ & $\%$ & $\mathrm{~T} 1$ & $\mathrm{~T} 2$ & $\%$ \\
\hline One step & 1 & 1 & 5.0 & 2 & 1 & 7.9 \\
\hline Two steps & 4 & 2 & 15.0 & 8 & 5 & 34.2 \\
\hline Three steps & 3 & 2 & 12.5 & 4 & 6 & 26.3 \\
\hline Four steps & 2 & 4 & 15.0 & 3 & 5 & 21.1 \\
\hline Five or more steps & 9 & 12 & 52.5 & 2 & 2 & 10.5 \\
\hline Total & 19 & 21 & 100.0 & 19 & 19 & 100.0 \\
\hline
\end{tabular}

According to the table, the difference in averages also reflects the number of problems requiring four or more steps to solve, since the talent group proposed $67.5 \%$ problems of this type and the standard group $31.6 \%$. Another interesting finding is that students in the standard group posed a large number of problems that required 2-4 steps to solve $(81.6 \%)$, whereas the talent group posed $42.5 \%$ that present this characteristic. Statistically, there are significant differences between the two groups, with a p-value for the Chi-square test of 0.003 .

In examining problem solvability, we find that the problems posed by the talent group required on average a higher number of steps to solve solvable problems (4.04) than to solve unsolvable problems (3.81), whereas the standard group's average number of steps is higher for unsolvable (3.4) than for solvable problems (2.75). Further, the standard group posed a larger proportion of unsolvable problems with more than four steps $(50 \%)$ than of solvable problems with this characteristic $(26 \%)$.

\section{Analysis by semantic structure}

In this category, as in the previous one, we analyzed only 78 problems.

Semantic structure of additive problems. In studying only the problems with additive structure, we find that the talent group posed only one additive statement, a problem with a semantic structure of change, whereas the standard group produced 8 problems of this type, 4 with a semantic structure of combination, 3 of change, and 1 of comparison. In the 59 problems with additive or mixed structure ( 33 posed by the talent group and 26 by the standard group), on the other hand, both groups preferred combination problems, followed by problems that include the semantic component of change. 
Semantic structure of multiplicative problems. The semantic structures most frequently used by the talent group were product of measures (71.4\%) and isomorphism of measures (57.1\%). In the case of the standard group, $91.7 \%$ of the multiplicative problems show the semantic relationship of isomorphism of measures and $25 \%$ product of measures. The 72 multiplicative or mixed problems (39 proposed by the talent group and 33 by the standard group), on the other hand, showed that both groups preferred posing problems that included the semantic component of isomorphism of measure, followed by product of measures and, in lower proportion, multiplicative comparison.

Semantic relationships involved in the mixed problems. We find that $66 \%$ of the mixed problems posed by the standard group included semantic components of combinationisomorphism of measures or change-isomorphism of measures, whereas the talent group posed only $13 \%$ problems with these characteristics. In the case of the talent group, we cannot establish a majority of specific combinations of additive and multiplicative semantic structures in the mixed problems, but the most frequent combinations (30\%) are changecombination-isomorphism of measures and change-additive comparison-isomorphism of measures.

Number of different semantic relationships. We see that the average number of different semantic relationships is greater in the talent group (2.83) than in the standard group (1.89). The following table provides more in-depth information on this variable.

Table 7. Classification of problems by number of different relationships of semantic structure, task, and group to which the student belongs

\begin{tabular}{|c|c|c|c|c|c|c|c|c|}
\hline \multirow{2}{*}{$\begin{array}{c}\text { Number of different } \\
\text { semantic relationships }\end{array}$} & \multicolumn{4}{|c|}{ Talent group } & \multicolumn{4}{|c|}{ Standard group } \\
\hline & T1 & $\mathrm{T} 2$ & Total & $\%$ & $\mathrm{~T} 1$ & $\mathrm{~T} 2$ & Total & $\%$ \\
\hline One relationship & 3 & 1 & 4 & 10.0 & 7 & 3 & 10 & 26.3 \\
\hline Two relationships & 6 & 4 & 10 & 25.0 & 10 & 12 & 22 & 57.9 \\
\hline Three relationships & 9 & 8 & 17 & 42.5 & 2 & 4 & 6 & 15.8 \\
\hline Four relationships & 1 & 6 & 7 & 17.5 & 0 & 0 & 0 & 0.0 \\
\hline $\begin{array}{l}\text { Five or more relation- } \\
\text { ships }\end{array}$ & 0 & 2 & 2 & 5.0 & 0 & 0 & 0 & 0.0 \\
\hline Total & 19 & 21 & 40 & 100.0 & 19 & 19 & 38 & 100.0 \\
\hline
\end{tabular}

Table 7 shows that the talent group posed a higher proportion $(65 \%)$ of problems with three or more different semantic relationships than did their classmates in the standard group (15.8). Further, all problems produced by the standard group have three or fewer different 


\section{Johan Espinoza et al.}

semantic relationships, and a significant percentage have two or fewer (84.2\%). The talent and standard groups propose similar percentages of problems with two or three different semantic relationships (67.5\% and 73.7, respectively). The p-value associated with the Chisquare test is 0.00 , demonstrating the significance of the differences between the two groups.

\section{Discussion and conclusions}

First, we believe that the problem-posing instrument and the analytic diagram used in this research enable us to describe and explore the action of a group of mathematically talented students. Next, the three categories of analysis used in solving each problem give rise to ten components whose values characterize the richness of the problems the subjects pose: length of statement, interrogative proposition, numbers used, operator structure, number of stages, type of operation, number of processes, number of steps in solving, semantic structure, and number of semantic relationships. Further, we confirm statistically significant differences in the productions of the two study groups.

We conclude that the problems posed by the talent group show greater richness than those posed by the standard group, since the former are composed of a greater number of propositions and types of numbers, require more steps and different calculation processes to solve, and show a greater number of different semantic relationships. This result is similar to that obtained by Ellerton (1986), as the problems posed by more able students require greater calculation difficulty, have a higher number of operations, and involve a more complex number system than those posed by their classmates with less ability.

As to the solvability of the problems, we conclude that the unsolvable problems posed by the talent group show a greater number of propositions, types of numbers, and different semantic relationships than the solvable ones, but the latter require a greater number of steps to solve. We also observe that the talent group posed a higher proportion of unsolvable problems with mixed structure and presented designative interrogative propositions.

We believe this result this may be due to the fact that the students attempted to add conditions to the problem to make it more difficult, without verifying whether it was solvable. In spite of this result, we believe that it is important to analyze the problems, since posing a solvable problem is an additional part of the complexity involved in the activity of posing a 
difficult problem. Further, a large proportion of these problems showed numerical mathematical incompatibility, but they are statements with great richness according to the study variables analyzed.

After analyzing the talent students' productions based on the analytic diagram and the three categories of analysis defined in this study, and taking into account the study conditions and results, we conclude that a mathematically talented student can be characterized as:

a) Posing a large number of unsolvable problems.

b) Including five or more propositions in the problem statement.

c) Using natural numbers and a lower proportion of rational numbers.

d) Using two different types of numbers, whether natural or rational, expressed in decimal notation and/or as a fraction.

e) Including designative interrogative propositions as the problem question.

f) Combining additive and multiplicative structures to pose problems of mixed structure.

g) Including semantic relationships of combination and product of measures.

h) Proposing three or more different semantic relationships.

i) Posing problems that require four or more steps to solve.

j) Posing problems that require two or more different calculation processes to solve and, to a lesser extent, three or more processes.

Finally, we conclude that problem-posing activities can be considered in identifying mathematically talented students. This conclusion is based on the finding that the students in the talent group showed greater capability for posing problems with richness than their classmates in the standard group. Further, we perceive greater difficulty in solving the problems posed by the standard group, since, when they read the statement, they did not immediately identify its solution.

\section{References}

Ayllón, M. (2012). Invención-Resolución de problemas por alumnos de educación primaria. Doctoral thesis. Granada: University of Granada.

Banfield, T. (2005). Ability grouping for mathematically gifted adolescent boys. International Journal, 6(2), 141-149. 
Benavides, M. (2008). Caracterización de sujetos con talento en resolución de problemas de estructura multiplicativa. Doctoral thesis. Granada: University of Granada.

Brown, S. \& Walter, M. (1990). The art of problem posing. New Jersey: Lawrence Erlbaum Associates.

Brown, S. \& Walter, M. (1993). Problem posing. New Jersey: Lawrence Erlbaum Associates.

Castro, E. (1995). Niveles de comprensión en problemas verbales de comparación multiplicativa. Granada: Comares.

Castro, E. (1991). Resolución de problemas aritméticos de comparación multiplicativa. Doctoral thesis. Granada: University of Granada.

Castro, E., Rico, L. \& Gil, F. (1992). Enfoque de investigación en problemas verbales aritméticos aditivos. Enseñanza de las Ciencias, 10(3), 243-253.

Castro, E., Castro, E., Rico, L., Gutiérrez, J., Tortosa, A., Segovia, I. et al. (1997). Problemas aritméticos compuestos de dos relaciones. In L. Rico \& M. Sierra (Eds.), Primer simposio nacional de la SEIEM (pp. 63-76). Granada: SEIEM.

Castro, E. (2008). Resolución de problemas: Ideas, tendencias e influencias en España. In R. Luengo, B. Gómez, M. Camacho \& L. Blanco (Eds.), Investigación en Educación Matemática XII (pp. 113-140). Badajoz: Sociedad Española de Investigación en Educación Matemática, SEIEM.

Castro, E. (2011). La invención de problemas y sus ámbitos de investigación. In J. L. Lupiáñez, M. C. Cañadas, M. Molina, M. Palarea \& A. Maz (Eds.), Investigaciones en Pensamiento Numérico y Algebraico e Historia de la Matemática y Educación Matemática (pp. 1-15). Granada, Departament of Mathematics Education, University of Granada.

Cázares, J. (2000). La invención de problemas en escolares de primaria: Un estudio evolutivo. Granada: University of Granada.

Ellerton, N. (1986). Children's made up mathematics problems: A new perspective on talented mathematicians. Educational Studies in Mathematics, 17(3), 261-271. doi: 10.1007/BF00305073

English, L. (1997). The development of fifth-grade children's problem-posing abilities. Educational Studies in Mathematics, 34(3), 183-217. doi: 10.1023/A:1002963618035

Espinoza, J., Lupiáñez, J. L. \& Segovia, I. (2014). La invención de problemas y sus ámbitos de investigación en Educación Matemática. Revista digital Matemática, Educación e Internet (14)2, 1-12. doi:10.18845/rdmei.v14i2.1664 
Espinoza, J., Lupiáñez J. L. \& Segovia, I. (2015). Un esquema para analizar los enunciados de los estudiantes en contextos de invención de problemas. Revista Unciencia (29)1, 5881. doi:10.15359/ru.29-1.4

Freiman, V. (2006). Problems to discover and to boost mathematical talent in early grades: A challenging situations approach. The Montana Mathematics Enthusiast, 3(1), 51-75.

Freudenthal, H. (1973). Mathematics as an educational task. Dordrecht: Reidel.

Gasco, J. \& Villarroel, J. D. (2014). La motivación en la resolución de problemas aritméticoalgebraicos: Un estudio con alumnado de educación secundaria. Electronic Journal of Research in Educational Psychology, 12(1), 83-106. doi:10.14204/ejrep.32.13076

Greenes, C. (1981). Identifying the gifted student in mathematics. Arithmetic Teacher, 28(8), 14-17.

Hernández, D. \& Gutiérrez, M. (2014). El estudio de la alta capacidad intelectual en España: Análisis de la situación actual. Revista de Educación, 364, 251-272. doi: 10.4438/1988-592X-RE-2014-364-261

Kilpatrick, J. (1987). Problem formulating: Where do good problems come from? In A. Shoenfeld (Ed.) Cognitive science and mathematics education. (pp. 123-148). New Jersey: Lawrence Erlbaum Associates.

Krutetskii, V. A. (1976). The psychology of mathematical abilities in school children. Chicago: University of Chicago Press.

Kesan, C., Kaya, D. \& Güvercin, S. (2010). The effect of problem posing approach to the gifted student's mathematical abilities. International Online Journal of Educational Sciences, 2(3), 677-687.

Leung, S. \& Silver, E. (1997). The role of task format, mathematics knowledge, and creative thinking on the arithmetic problem posing of prospective elementary school teachers. Mathematics Education Research Journal, 9(1), 5-24. doi: 10.1007/BF03217299

Marugan, M., Carbonero M. A., Torres, M. \& Leon, B. (2012). Análisis de las relaciones entre creatividad y altas capacidades en primaria y secundaria. Electronic Journal of Research in Educational Psychology, 10(3), 1081-1098.

Moses, B., Bjork, E. \& Goldenberg, E. R. (1990). Beyond problem solving: Problem posing. In T. J. Cooney \& C. R. Hirsch (eds.), Teaching and learning mathematics in the 1990s (pp. 83-91). Reston, VA: National Council of Teachers of Mathematics.

National Council of Teachers of Mathematics. (1980). An agenda for action: Recommendations for school mathematics of the 1980s. Reston, VA: Autor. 
National Council of Teachers of Mathematics. (2000). Principles and standards for school mathematics. Reston, VA: Autor.

Pasarín, M. J., Feijoo, M., Díaz, O. \& Rodríguez, L. (2004). Evaluación del talento matemático en educación secundaria. Faísca, Revista de altas capacidades, 11, 83-102.

Passow, A. (1993). National/state policies regarding education of the gifted. In K. Heller, F. Monks \& A. Passow (Eds.), International Handbook of Research and Development of Giftedness and Talent (pp. 29-46). Oxford: Pergamon Press.

Pelczer, I. \& Gamboa F. (2008). Problem posing strategies of mathematically gifted students. In R. Leikin (Ed.), Proceedings of the 5th International Conference on Creativity in Mathematics and the Education of Gifted Students (pp. 193-199). Tel Aviv: Center for Educational Technology.

Polya, G. (1954). Mathematics and plausible reasoning. Princeton, NJ: Princeton University Press.

Polya, G. (1979). Cómo plantear y resolver problemas. Mexico: Trillas.

Puig, L. \& Cerdán, F. (1988). Problemas aritméticos. Madrid: Síntesis.

Ramírez, R. (2012). Habilidades de visualización de los alumnos con talento matemático. Doctoral thesis. Granada: University of Granada.

Silver, E. (1994). On mathematical problem posing. For the Learning of Mathematics, 14(1), $19-28$.

Silver, E. \& Cai, J. (1996). An analysis of arithmetic problem posing by middle school students. Journal for Research in Mathematics Education, 27(5), 521-539. doi: $10.2307 / 749846$

Silver, E. \& Cai, J. (2005). Assessing students' mathematical problem posing. Teaching Children Mathematics, 12(3), 129-135.

Stoyanova, E. (1998). Problem posing in mathematics classrooms. In A. McIntosh \& N. Ellerton (Eds.), Research in mathematics education: a contemporary perspective. (pp. 164185). Edit Cowan University: MASTEC.

Villarraga, M., Martínez, P. \& Benavides, M. (2004). Hacia la definición del término talento. In M. Benavides, A. Maz, E. Castro \& Blanco, R. (Eds.), La educación de niños con talento en Iberoamérica (pp. 25-35). Santiago, Chile: OREALC/Unesco. 
The Posing of Arithmetic Problems by Mathematically Talented Students

Page intentionally without text to adjust both language versions 